\title{
Value of Ascitic Lipids in the Differentiation Between Cirrhotic and Malignant Ascites
}

\author{
Dieter Jüngst, Alexander L. Gerbes, Robert Martin and Gustav Paumgartner \\ Department of Internal Medicine II, Klinikum Grosshadern, University of Munich, Federal Republic of Germany
}

\begin{abstract}
Ascitic fluid concentrations of cholesterol, triglycerides and phospholipids, were compared with ascitic fluid total protein in 40 patients with chronic liver disease, 51 patients with various neoplasms and 1 patient with cardiac failure. Seven patients with both chronic liver disease and malignancy were considered separately. The first 54 patients (23 cirrhotic and 31 with malignancy) were used to determine median values and ranges and to define the most suitable cutoff concentrations between both groups. Median values for cholesterol (75 mg per dl), phospholipids 0.79 mmole per liter), triglycerides (75 $\mathrm{mg}$ per $\mathrm{dl}$ ) and protein $(3.8 \mathrm{gm}$ per dl) were higher in malignant ascites compared to ascitic fluid concentrations of cholesterol ( $20 \mathrm{mg}$ per $\mathrm{dl}$ ), phospholipids ( 0.33 mmole per liter), triglycerides ( $51 \mathrm{mg}$ per $\mathrm{dl}$ ) and protein $(1.9 \mathrm{gm}$ per $\mathrm{dl}$ ) in patients with cirrhosis. The best discrimination values were $48 \mathrm{mg}$ per $\mathrm{dl}$ for cholesterol, 0.6 mmole per liter for phospholipids, 65 mg per dl for triglycerides and $2.5 \mathrm{gm}$ per $\mathrm{dl}$ for protein. Application of these cutoff points to 38 subsequent patients (17 cirrhotic, 1 with cardiac failure and 20 with malignancy) revealed an efficiency of $\mathbf{8 6 . 8 \%}$ for cholesterol, $\mathbf{8 6 . 8 \%}$ for phospholipids, $68.4 \%$ for triglycerides and $79.0 \%$ for protein. From the data of all 92 patients, an efficiency of $92.3 \%$ for cholesterol, $79.4 \%$ for phospholipids, 72.8\% for triglycerides and $79.4 \%$ for protein was calculated.

We conclude that ascitic fluid cholesterol determination offers an excellent, cost-effective discrimination of ascites due to cirrhosis vs. ascites caused by malignancies.
\end{abstract}

Ascites is most often caused by either chronic liver disease or malignant neoplasms, and ascitic fluid (AF) parameters valuable for the differential diagnosis of these have long been sought. Cytological investigation, despite its high specificity, has been found unreliable in many cases due to the high percentage of false-negative results (1).

AF total protein has been used widely as a laboratory test in this differential diagnosis $(2,3)$. However, high protein ascites, although a consistent finding in malignant $\mathrm{AF}$, has been reported in up to $25 \%$ of patients with

Received January 23, 1985; accepted September 9, 1985.

A portion of this study was presented at the 86th Annual Meeting of the American Gastroenterological Association, New York, 1985.

Address reprint requests to: Dieter Jüngst, M.D., Department of Medicine II, Klinikum Grosshadern, Marchioninistr. 15, D-8000 Munich 70, Federal Republic of Germany. chronic liver disease $(4,5)$. Other parameters such as AF lactate dehydrogenase, carcinoembryonic antigen or fibrinogen degradation products have been investigated, but a complete separation between malignant and cirrhotic ascites has not been achieved (6-10). Lipid analysis in AF has been performed only in a few studies demonstrating elevated concentrations of total lipids as well as cholesterol in ascites of malignant origin compared to ascites caused by chronic liver disease $(3,11)$.

Nevertheless, the diagnostic value of lipid determination in AF has not been evaluated further. The purpose of the present study was to investigate the efficacy of AF lipid analysis in discriminating between malignant ascites from ascites caused by cirrhosis.

\section{MATERIALS AND METHODS}

Patients. Ninety-nine consecutive ascitic patients (51 with neoplasms metastatic to the peritoneum, 40 with cirrhotic ascites and 1 with cardiac failure) were studied prospectively. Seven patients with ascites suffered from both: chronic liver disease and malignancies. As the cause of ascites could not be clearly classified, they were considered separately. The first 54 patients ( 23 cirrhotic and 31 with malignancy) were analyzed to determine median values and ranges and to define threshold concentrations for cholesterol, phospholipids, triglycerides and total protein between both groups. The group with chronic liver disease consisted of 12 patients with alcoholic and 10 patients with posthepatitic cirrhosis and 1 patient with Budd-Chiari syndrome. In the 31 patients with malignant ascites, there were 12 subjects with ovarian carcinoma, 11 with breast cancer and 8 with carcinoma of the pancreas, gallbladder, esophagus, stomach or uterus and peritoneal mesothelioma, teratoma and osteosarcoma, respectively.

For further evaluation of the results obtained in the first 54 patients, an independent group of 38 patients (17 cirrhotic, 1 cardiac and 20 with maligancy) was studied consecutively.

Diagnoses in all patients with liver disease were confirmed by liver biopsy. Hepatic malignancy was excluded in these patients by ultrasound, scintigraphy, or computer tomography and, in some, by laparoscopy and autopsy. Patients with ascites classified as malignant had a primary or metastatic malignancy in the abdomen or pelvis. In some of these patients, the definitive diagnosis was made at autopsy.

Methods. Cytological examination was performed within $2 \mathrm{hr}$ of aspiration of AF on Papanicolaou and Giemsa-stained smears of the sediment which was obtained by centrifugation of 10 to $20 \mathrm{ml}$ samples at $3,000 \mathrm{rpm}$ for $10 \mathrm{~min}$. The supernatant was stored at $-80^{\circ} \mathrm{C}$ for further biochemical analysis.

Total protein was determined by a commercial biuret method (Merck, Darmstadt, Federal Republic of Germany). Phospho- 
lipids were measured after extraction (chloroform-methanol $3: 1, v / v)$ by phosphorus analysis (12). Triglycerides and cholesterol were quantitated enzymatically with commercial test kits (Boehringer Mannheim, Federal Republic of Germany) (13, 14). As there was no random distribution of data, the results are given as median and range in addition to mean and standard deviation. For further statistical analysis, the Mann-Whitney test was used. A p value of $<0.05$ was considered statistically significant.

The data of the first 54 patients were used to determine the most suitable discriminating concentrations for AF lipids and protein. Applying these limits to the 38 patients subsequently studied and to the total of 92 patients permitted classification into four categories: true positive (a); true negative (b); false positive (c), and false negative (d).

Sensitivity was calculated as $[a /(a+d)] \times 100$, specificity as $[b /(b+c)] \times 100$ and efficiency as $[a+b /(a+b+c+d)] \times$ $100(15)$.

\section{RESULTS}

Concentrations of the determined parameters in the AF of the first 54 patients are illustrated in Figure 1. Median values for cholesterol ( $75 \mathrm{mg}$ per $\mathrm{dl}$ ), phospholipids ( 0.79 mmole per liter), triglycerides ( $75 \mathrm{mg}$ per $\mathrm{dl}$ ), and protein (3.8 gm per $\mathrm{dl}$ ) were significantly higher in malignant ascites compared to the median AF concentrations of cholesterol ( $20 \mathrm{mg}$ per $\mathrm{dl})$, phospholipids ( 0.33 mmole per liter), triglycerides (51 $\mathrm{mg}$ per $\mathrm{dl}$ ) and protein
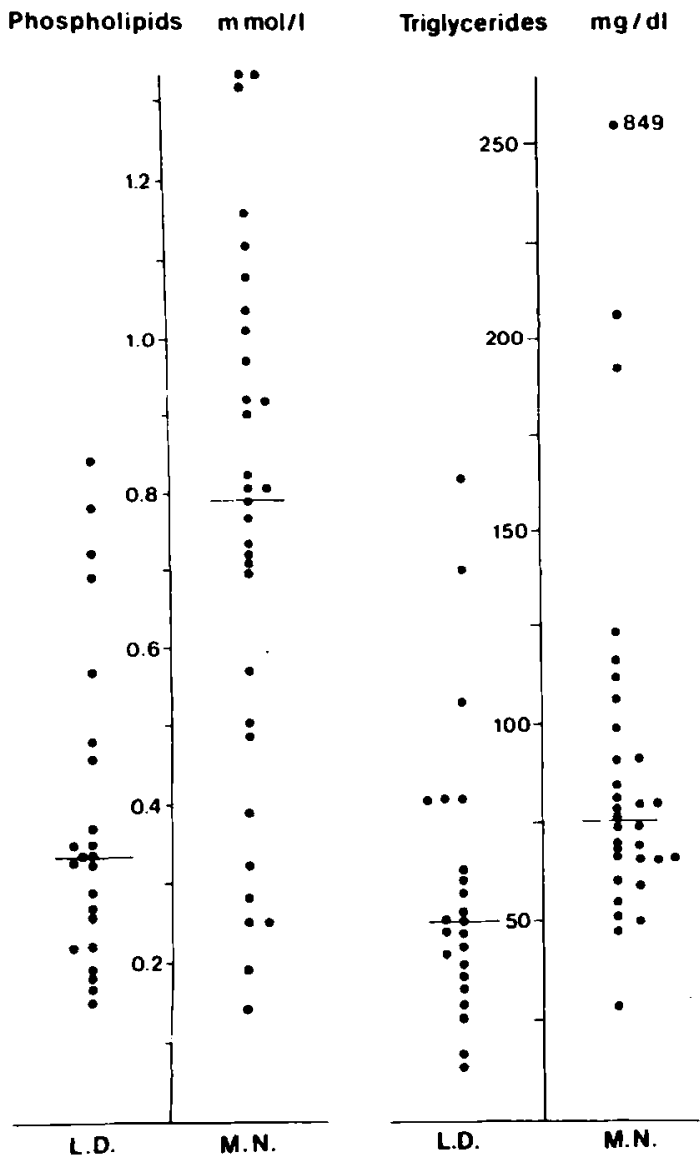

(1.9 gm per dl) in patients with cirrhosis (Figure 1). The best discriminating values were $48 \mathrm{mg}$ per $\mathrm{dl}$ for cholesterol, 0.6 mmole per liter for phospholipids, $65 \mathrm{mg}$ per dl for triglycerides and $2.5 \mathrm{gm}$ per dl for protein.

AF concentrations of lipids and protein in the 38 subsequent patients are illustrated in Table 1.

Applying the discrimination values defined from the data of the first 54 patients to the 38 subsequent patients, sensitivity, specificity and efficiency were calculated (Table 2). Diagnostic efficiency ranged between 68.4 and $86.8 \%$ in this reevaluation study, and cholesterol and phospholipid determinations were superior to the other parameters. From the results of all 92 patients, an efficiency of $92.3 \%$ for cholesterol, $79.4 \%$ for phospholipids, $72.8 \%$ for triglycerides and $79.4 \%$ for protein was calculated (Table 3). AF cholesterol measurement yielded the best discrimination: only 5 patients with malignant and 2 patients with cirrhotic ascites were incorrectly classified at a cutoff concentration of $48 \mathrm{mg}$ per dl.

Cytological examination was performed in 28 of 41 patients with nonmalignant ascites and in 37 of 51 patients with ascites due to malignant neoplasms. Diagnostic specificity was found to be $100 \%$. However, sensitivity was only $62 \%$ because of a great number of false-negative results. There was no correlation between the concentrations of triglycerides and the other lipids or total protein in $\mathrm{AF}$ of the 92 patients, indicating a different mechanism of triglyceride accumulation in ascites. However,

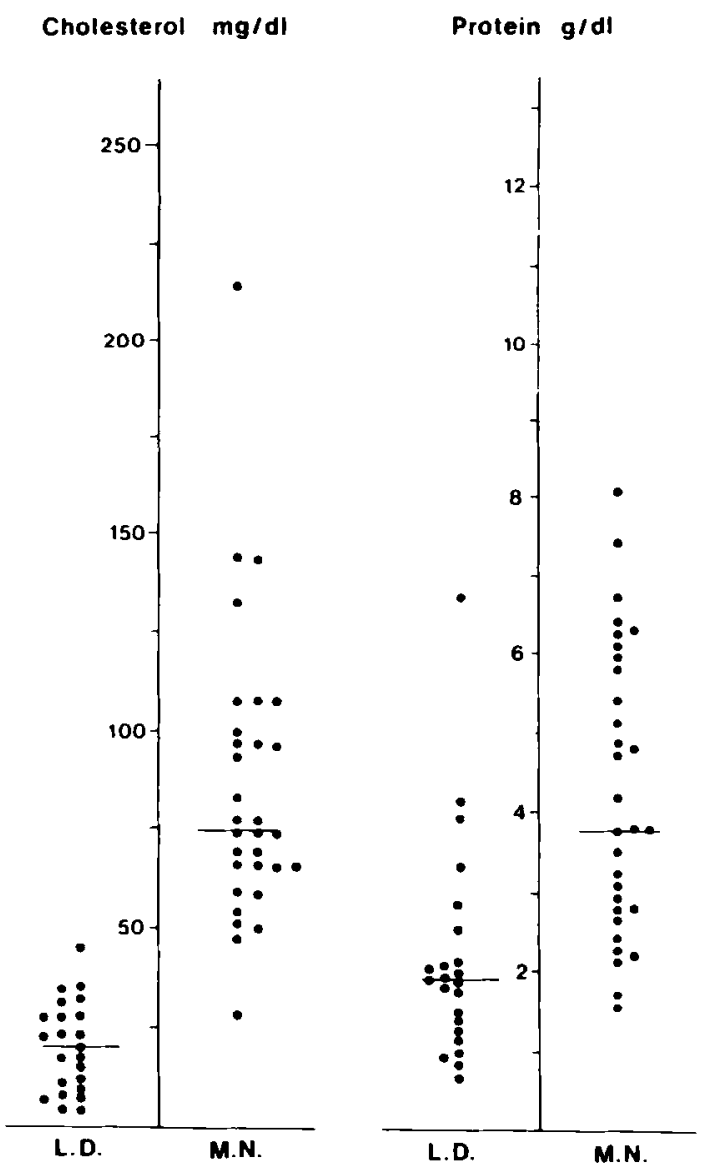

FIG. 1. Scattergram distribution of AF phospholipids, triglycerides, cholesterol and total protein in 23 patients with liver disease (L.D.) and 31 patients with malignant neoplasm (M.N.). $-=$ median value. 
Table 1. Concentration of af Lipids and Protein in Patients with Cirrhotic and Malignant ascites

\begin{tabular}{|c|c|c|c|c|c|}
\hline & $\begin{array}{c}\text { No. of } \\
\text { patients }\end{array}$ & $\begin{array}{l}\text { Chalesterol } \\
(\mathrm{mg} / \mathrm{dl})\end{array}$ & $\begin{array}{l}\text { Phospholipids } \\
\text { (mmole/liter) }\end{array}$ & $\begin{array}{c}\text { Triglycerides } \\
\text { (mg/dl) }\end{array}$ & $\begin{array}{l}\text { Protein } \\
\text { (gm/dl) }\end{array}$ \\
\hline Cirrhotic ascites & 18 & & & & \\
\hline Median & & 23 & 0.32 & 32 & 1.9 \\
\hline Mean \pm S.D. & & $26.5 \pm 17.3$ & $0.37 \pm 0.18$ & $51 \pm 59$ & $2.1 \pm 1.5$ \\
\hline Malignant ascites & 20 & & & & \\
\hline Mean \pm S.D. & & $74 \pm 26$ & $0.76 \pm 0.18$ & $76 \pm 50$ & $4.0 \pm 1.0$ \\
\hline
\end{tabular}

${ }^{a}$ Difference between the mean of cirrhotic and malignant concentrations is statistically significant, $\mathrm{p}<0.001$.

${ }^{b}$ Not statistically significant.

Table 2. Diagnostic Value of Ascitic Ljpids and Protein for SeParating Ascites of Nonmalignant ORigin $(\mathrm{n}=18)$ From Ascites Due to Various NeOplasms $(\mathbf{n}=20)$

\begin{tabular}{lcccc}
\hline & $\begin{array}{c}\text { Discrimination } \\
\text { value }\end{array}$ & $\begin{array}{c}\text { Sensitivity } \\
(\%)\end{array}$ & $\begin{array}{c}\text { Specificity } \\
(\%)\end{array}$ & $\begin{array}{c}\text { Efficiency } \\
(\%)\end{array}$ \\
\hline Cholesterol & $48 \mathrm{mg} / \mathrm{dl}$ & 85.0 & 88.9 & 86.8 \\
Phospholipids & $0.6 \mathrm{mmole} / \mathrm{liter}$ & 85.0 & 88.9 & 86.8 \\
Triglycerides & $65 \mathrm{mg} / \mathrm{dl}$ & 65.0 & 72.2 & 68.4 \\
Protein & $2.5 \mathrm{gm} / \mathrm{dl}$ & 85.0 & 72.2 & 79.0 \\
\hline
\end{tabular}

significantly positive correlations were found between cholesterol/phospholipids ( $\mathrm{r}=0.59$ ), cholesterol/total protein $(\mathrm{r}=0.56)$ and phospholipids/total protein $(\mathrm{r}=$ 0.55 ) (Figure 2, a to c).

Table 4 presents concentrations of AF lipids and protein found in seven patients with both chronic liver disease and malignancy. In three subjects, posthepatitic cirrhosis was the underlying disease associated with a histologically proven hepatocellular carcinoma. Low AF cholesterol levels of 5 to $11 \mathrm{mg}$ per dl suggested that ascites was most likely caused by cirrhosis. In two patients suffering from cirrhosis, a hepatocellular carcinoma was suggested by ultrasound and computed tomography but not proven by histological examination. One patient had Laennec's cirrhosis and a history of carcinomas of the breast and thyroid, which had been operated successfully years ago. There was no clinical evidence of metastases. AF cytology was negative, cholesterol, protein and triglycerides were below the cutoff values and only phospholipids were slightly elevated.

Another cirrhotic suffered from an osteofibrosis, the cause of which could not clarified, but chronic myeloid leukemia could not be excluded with certainty.

\section{DISCUSSION}

In 1958, Rovelstad et al. (3) reported elevated total lipid concentrations in the ascites of patients with malignant neoplasms. Polak et al. (11) demonstrated a marked elevation of total cholesterol in malignant and inflammatory AF compared to cirrhotic ascitic fluid. In the present study, we investigated the value of AF lipids in the discrimination of ascites caused by chronic liver disease and ascites due to malignancies.

In a preliminary study of 54 patients (Figure 1), 29 of 31 patients with malignant ascites had an $\mathrm{AF}$ cholesterol concentration higher than $48 \mathrm{mg}$ per $\mathrm{dl}$, while all 23
Table 3. Diagnostic Value of ascitic Lipids and Protein for Separating ascites of Nonmalignant Origin $(n=41)$ From Ascites Due to Various NeOPLASMS $(n=51)$

\begin{tabular}{lcccc}
\hline & $\begin{array}{c}\text { Discrimination } \\
\text { value }\end{array}$ & $\begin{array}{c}\text { Sensitivity } \\
(\%)\end{array}$ & $\begin{array}{c}\text { Specificity } \\
(\%)\end{array}$ & $\begin{array}{c}\text { Efficiency } \\
(\%)\end{array}$ \\
\hline Cholesterol & $48 \mathrm{mg} / \mathrm{dl}$ & 90.1 & 95.1 & 92.3 \\
Phospholipids & $\mathbf{0 . 6 \mathrm { mmole } / \text { liter }}$ & 72.5 & 85.3 & 79.4 \\
Triglycerides & $65 \mathrm{mg} / \mathrm{dl}$ & 72.5 & 73.1 & 72.8 \\
Protein & $2.5 \mathrm{gm} / \mathrm{dl}$ & 82.3 & 75.6 & 79.4 \\
\hline
\end{tabular}

patients with ascites and chronic liver disease showed AF cholesterol below this value. The efficiency of AF cholesterol in the discrimination of malignant from cirrhotic ascites was slightly lower $(86.8 \%)$ in a prospective reevaluation of 38 subsequent patients. An equal efficiency in these 38 patients was calculated for AF phospholipids, while triglyceride and protein determinations were less effective. In the total of 92 patients, AF cholesterol determination was superior to the other parameters with a diagnostic efficiency of $92.3 \%$ compared to $79.4 \%$ for phospholipids, $72.8 \%$ for triglycerides and $79.4 \%$ for total protein.

There was a positive correlation between AF concentrations of cholesterol, phospholipids and protein but not between these and AF triglycerides. The potential rationale for these observations is most likely an increased filtration of plasma proteins and lipoproteins in the presence of peritoneal disorders such as peritoneal carcinomatosis. In accordance with this suggestion, plasma lipoproteins have been isolated and characterized from human AF recently (16). Although it is known that patients with cirrhosis often present low plasma cholesterol levels, this observation could not explain solely the large difference between the AF cholesterol in cirrhotic and malignant ascites. In some of the patients, plasma cholesterol and AF cholesterol were determined simultaneously. No significant difference was obtained between plasma levels of cholesterol in patients with chronic liver disease and patients with malignancies. Plasma AF gradients of cholesterol were increased in liver disease compared to malignancies due to low AF cholesterol. However, plasma-AF gradients of cholesterol did not provide a better discrimination than the AF cholesterol concentration alone.

Nevertheless, plasma AF gradients of proteins might be of greater diagnostic value than the determination of 

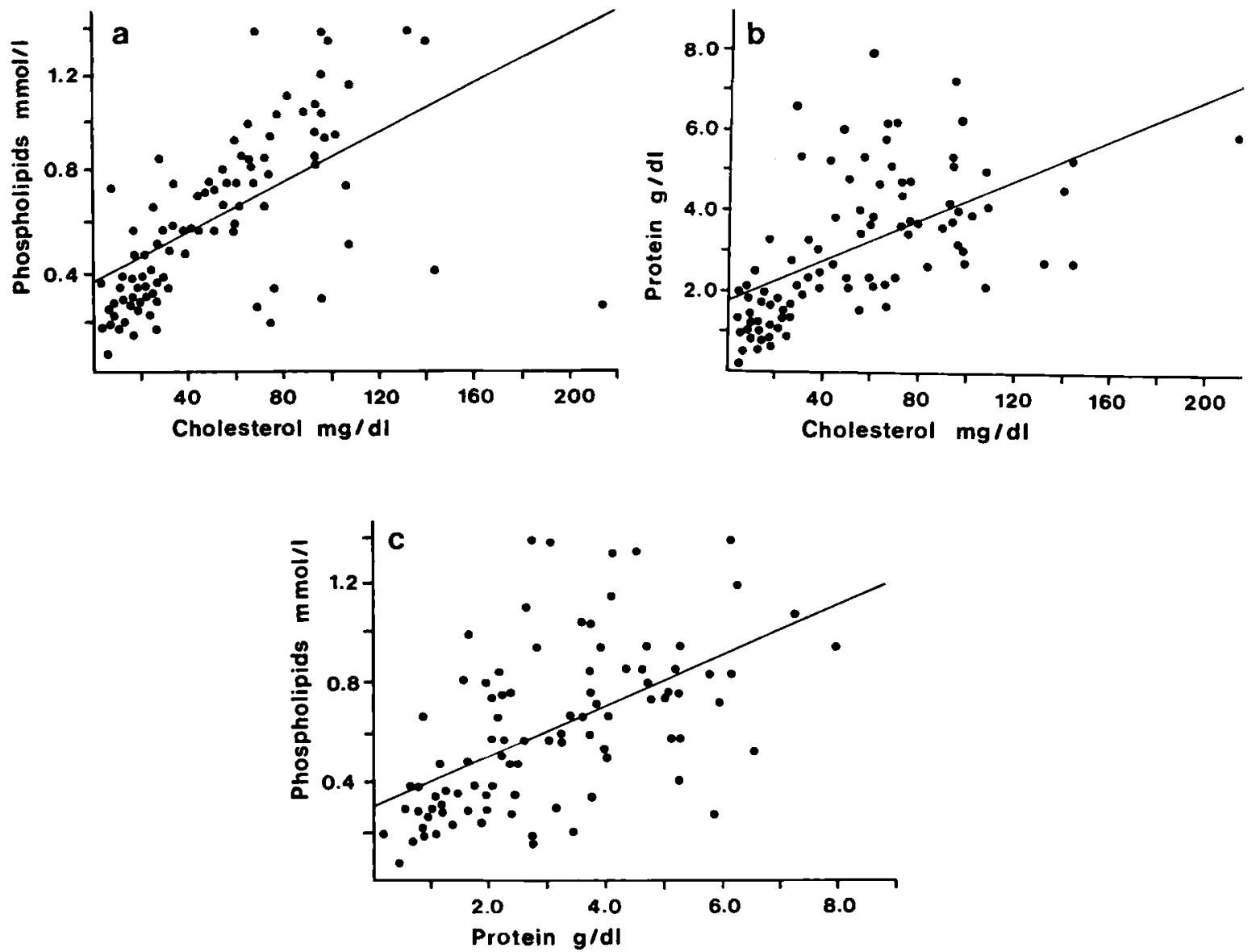

Fig. 2. (a) Correlation of ascitic phospholipids and cholesterol in 92 patients with ascites of malignant or nonmalignant origin ( $r=0.59$; $p<$ 0.001 ). (b) Correlation of ascitic cholesterol and protein in 92 patients with ascites of malignant or nonmalignant origin ( $r=0.56 ; p<0.001)$. (c) Correlation of ascitic phospholipids and total protein in 92 patients with ascites of malignant or nonmalignant origin $(r=0.55 ; \mathrm{p}<0.001)$.

Table 4. Concentration of Ascitic Lipids and Protein in Seven Patients with ascites Whose Origin Could Not Be Clearly Classified

\begin{tabular}{|c|c|c|c|c|}
\hline Diagnosis & $\begin{array}{c}\text { Cholesterol } \\
(\mathrm{mg} / \mathrm{dl})\end{array}$ & $\begin{array}{c}\text { Triglycerides } \\
\text { (mg/dl) }\end{array}$ & $\begin{array}{l}\text { Phospholipids } \\
\text { (mmole/liter) }\end{array}$ & $\begin{array}{l}\text { Protein } \\
\text { (gm/dl) }\end{array}$ \\
\hline $\begin{array}{l}\text { Cirrhosis and hepato- } \\
\text { cellular carcinoma }\end{array}$ & 11 & 184 & 0.21 & 0.8 \\
\hline $\begin{array}{c}\text { Cirrhosis and hepato- } \\
\text { cellular carcinoma }\end{array}$ & 5 & 12 & 0.09 & 1.5 \\
\hline $\begin{array}{l}\text { Cirrhosis and hepato- } \\
\text { cellular carcinoma }\end{array}$ & 11 & 33 & 0.22 & 4.2 \\
\hline $\begin{array}{l}\text { Cirrhosis and sus- } \\
\text { pected hepatocellu- } \\
\text { lar carcinoma }\end{array}$ & 17 & 27 & 0.36 & 0.7 \\
\hline $\begin{array}{l}\text { Cirrhosis and sus- } \\
\text { pected hepatocellu- } \\
\text { lar carcinoma }\end{array}$ & 29 & 45 & 0.52 & 3.2 \\
\hline $\begin{array}{l}\text { Cirrhosis, mammary } \\
\text { and thyroid carci- } \\
\text { noma }\end{array}$ & 26 & 14 & 0.65 & 0.9 \\
\hline $\begin{array}{l}\text { Osteofibrosis and cir- } \\
\text { rhosis }\end{array}$ & 22 & 80 & 0.33 & 2.7 \\
\hline
\end{tabular}

protein in AF only. In a recent study, Pare et al. (17) reported protein concentrations in cirrhotic or malignant ascites similar to those measured in our study.

Diagnostic efficiency of AF total protein determination was $80 \%$ in Pare's study as well as in our investigation.
Measurements of the AF to plasma ratio of total protein showed a similar efficiency in the discrimination of cirrhotic and malignant ascites as the determination of total $\mathrm{AF}$ protein alone.

However, diagnostic accuracy was much higher (95\%) for the plasma AF albumin gradient. In a recent study, Schölmerich et al. (18) demonstrated an excellent differentiation between malignant and nonmalignant ascites by the AF fibronectin concentration.

There is no doubt that the differential diagnosis of ascites can be improved by measurements of serum AF albumin gradient or fibronectin concentration. Our data suggest that the determination of AF cholesterol offers an equally effective discriminating test. However, the measurement of cholesterol might have considerable advantages in terms of simplicity and cost effectiveness.

As stated before, there was a positive correlation between AF concentrations of cholesterol and phospholipids, indicating a possible common mechanism of accumulation. Surprisingly, phospholipid determinations have been found less helpful for the discrimination of cirrhotic from malignant AF. This might be partially related to the method of extracting lipid from AF samples with organic solvents. Preliminary results suggest that a newly developed enzymatic method for phospholipid quantitation is more effective for this purpose (19).

No significant correlation was observed between AF 
cholesterol and triglyceride concentrations in AF. The concentration of triglycerides in AF is of no practical value in the differential diagnosis of ascites. The reason for these findings is not clearly understood. One possible explanation might be that triglycerides in AF are derived only in part from plasma, but chylomicrons of intestinal origin in variable amounts may contribute to the total amount of triglycerides in AF.

Further investigations are needed to elucidate the pathophysiology of lipid accumulations in the AF of patients with chronic liver disease, inflammatory and malignant peritoneal disorders.

Acknowledgments: We would like to thank Drs. W. Eiermann, J. Eisenburg, G. Geigenberger, R. Hörmann, B. Jacob, W. Klaubert, W. Kruis, G. Mannes, J. Mezger, D. Richter, B. Sperl and R. Zachoval for their collaboration in providing ascitic samples.

The authors are grateful to B. Hauserer, M. Bauch and A. Hohl for their technical assistance and to J. Steinberg for preparation of the manuscript.

\section{REFERENCES}

1. Tomb J. A cytopathological study on serous fluid in cancer. Lab Med J 1974; 27:51-58.

2. Paddock FK. The diagnostic significance of serous fluid in disease. N Engl J Med 1940; 223:1010-1015.

3. Rovelstad RA, Bartholomew LG, Cain JC, et al. I. The value of examination of ascitic fluid and blood for lipids and for proteins by electrophoresis. Gastroenterology $1958 ; 34: 436-450$.

4. Sampliner RE, Iber FL. High protein ascites in patients with uncomplicated hepatic cirrhosis. Am J Med Sci 1974; 267:275-279.

5. Boyer TD, Kahn AM, Reynolds TB. Diagnostic value of ascitic fluid lactic dehydrogenase, protein and WBC levels. Arch Intern Med 1978; 138:1103-1105.

6. Eimermacher H, Tinnefeld W, Prebler H, Schuster P, and Beyer
HK. Carcinoembryonales Antigen (CEA) und CEA-like Aktivität in Ascites und Pleuraergüssen. Klin Wochenschr 1979; 57:575-579.

7. Nystrom JS, Dyce B, Wada J, et al. Carcinoembryonic antigen titers in effusion fluid. Arch Intern Med 1977; 137:875-879.

8. Svanberg L, Astedt B. Coagulative and fibrinolytic properties of ascitic fluid associated with ovarian tumors. Cancer 1975; 35:13821387.

9. Greene LS, Levine R, Gross MJ, et al. Distinguishing between malignant and cirrhotic ascites by computerized step-wise discriminant functional analysis of its biochemistry. Am J Gastroenterol $1978 ; 70: 448-454$

10. Kirkeby K, Prydz H. LDH activity in pleural and peritoneal effusions. Scand J Clin Lab Invest 1959; 11:185-189.

11. Polak M, de Costa ACT, Bitelmann B, et al. Diagnostic value of the biochemical profile (protein, cholesterol, glucose, mucoprotein, amylase) of ascitic fluid. Rev Hosp Clin Fac Med S Paulo 1978; 33:186-199.

12. Fiske $\mathrm{CH}$, Subbarow $\mathrm{Y}$. The colorimetric determination of phosphorus. J Biol Chem 1925; 66:375-400.

13. Eggstein M. Eine neue Bestimmung der Neutralfette im Blutserum und Gewebe. II. Mitteilung. Zuverlässigkeit der Methode, andere Neutralfettbestimmungen, Normalwerte für Triglyceride und Glycerin im menschlichen Blut. Klin Wochenschr 1966; 44:267-273.

14. Röschlau P, Bernt E, Gruber W. Enzymatische Bestimmung des Gesamt-Cholesterins im Serum. Z Klin Chem Klin Biochem 1974; 12:403-407.

15. Galen RS, Gambino SR. Beyond normality-the predictive value and efficiency of medical diagnosis. New York: John Wiley and Sons, 1975.

16. Suzuki N, Kawashima S, Deguchi K, et al. Low density lipoproteins from human ascites plasma. J Biochem 1980; 87:1253-1256.

17. Pare P, Talbot J, Hoefs JC. Serum-ascites albumin concentration gradient: a physiologic approach to the differential diagnosis of ascites. Gastroenterology 1983; 85:240-244.

18. Schölmerich J, Volk BA, Köttgen E, et al. Fibronectin concentration in ascites differentiates between malignant and nonmalignant ascites. Gastroenterology 1984; 87:1160-1164.

19. Takayama $M$, Itoh $S$, Nagasaki $T$, et al. A new enzymatic method for determination of serum choline-containing phospholipids. Clin Chim Acta 1977; 79:93-98. 